\title{
Evolutionary Transitions in the Fossil Record of Terrestrial Hoofed Mammals
}

\author{
Donald R. Prothero
}

Published online: 16 April 2009

(C) Springer Science + Business Media, LLC 2009

\begin{abstract}
In the past few decades, many new discoveries have provided numerous transitional fossils that show the evolution of hoofed mammals from their primitive ancestors. We can now document the origin of the odd-toed perissodactyls, their early evolution when horses, brontotheres, rhinoceroses, and tapirs can barely be distinguished, and the subsequent evolution and radiation of these groups into distinctive lineages with many different species and interesting evolutionary transformations through time. Similarly, we can document the evolution of the even-toed artiodactyls from their earliest roots and their great radiation into pigs, peccaries, hippos, camels, and ruminants. We can trace the complex family histories in the camels and giraffes, whose earliest ancestors did not have humps or long necks and looked nothing like the modern descendants. Even the Proboscidea and Sirenia show many transitional fossils linking them to ancient ancestors that look nothing like modern elephants or manatees. All these facts show that creationist attacks on the fossil record of horses and other hoofed mammals are completely erroneous and deceptive. Their critiques of the evidence of hoofed mammal evolution are based entirely on reading trade books and quoting them out of context, not on any firsthand knowledge or training in paleontology or looking at the actual fossils.
\end{abstract}

Keywords Perissodactyl - Artiodactyl · Proboscideans . Tethytheres · Horses · Rhinoceroses · Tapirs · Brontotheres . Camels $\cdot$ Giraffes $\cdot$ Elephants $\cdot$ Sirenians

D. R. Prothero $(\bowtie)$

Department of Geology, Occidental College,

Los Angeles, CA 90041, USA

e-mail: Prothero@oxy.edu

\section{Introduction}

The hoofed mammals, or ungulates, are the third-largest group of placental mammals alive today (after rodents and bats). Nearly all large-bodied herbivorous mammals, living and extinct, are ungulates. These include not only familiar groups such as the odd-toed perissodactyls (horses, rhinos, and tapirs) and even-toed artiodactyls (pigs, peccaries, hippos, camels, deer, giraffes, pronghorns, cattle, sheep, and antelopes) but also their extinct relatives. Depending upon which phylogeny is accepted, many paleontologists also consider elephants, sirenians, and hyraxes to be ungulates as well (see Novacek 1986, 1992; Novacek and Wyss 1986; Novacek et al. 1988; Prothero et al. 1988; Prothero 1993; Prothero and Schoch 2002; Gheerbrant et al. 2005). Nearly all of these groups have an excellent fossil record since the early Eocene because they are relatively large-bodied with robust bones so they fossilize easily, and they were widespread among the Holarctic continents. Consequently, they provide a number of outstanding examples of evolution in the fossil record and are the focus of many creationist distortions and falsehoods about fossils as well.

Phylogenetically speaking, whales are also ungulates, since the molecular, paleontological, and morphological evidence has now converged on the idea that they are closest to the hippo-anthracothere branch of the artiodactyls (see Prothero and Foss 2007). Indeed, the earliest whales did have small hooves, although as whales reduced and lost their hind limbs and modified their forelimbs into flippers, their hooves were lost. The example of whale evolution is such an outstanding case of macroevolution, however, and has made so much recent progress with amazing new specimens that we have set it aside as a separate article (Thewissen, this volume). 
In this article, I will focus only on the best-documented examples of terrestrial hoofed mammals. These have proven to be historically important, ever since Huxley, Gaudry, and Kowalewsky first documented the fossil record of the evolution of the horse in Europe in the late 1860s and early 1870 s and then were upstaged by O.C. Marsh's incredible series of North American fossil horses in 1876 (MacFadden 1992). Fossil horses have since become one of the exemplars of evolution as displayed in the fossil record, endlessly repeated and recycled in textbooks and museum displays (but often with outdated or incorrect information). However, there are amazing evolutionary sequences known for tapirs, rhinos, brontotheres, camels, giraffes, and many other groups that receive much less notice. Here I will discuss just a few of these to allow the reader to see the incredible diversity of evidence for evolution that the fossil record provides. For more details, see Prothero (1994), Prothero and Schoch (2002), Chapter 14 in Prothero (2007), or the technical chapters in Prothero and Schoch (1989) and Prothero and Foss (2007).

\section{Odd Toes}

\section{The Perissodactyls}

The perissodactyls, or the odd-toed hoofed mammals, are not very diverse today. There are currently only four living species of tapirs, five species of rhinos, and a handful of species of horses, asses, and zebras. Most of these are endangered in the wild, and several have gone extinct in the last century. However, perrissodactyls were much more diverse in the Eocene and Oligocene, with a number of families and other lineages that are now extinct (e.g., brontotheres, palaeotheres, chalicotheres, lophiodonts, other tapiroids, hyracodonts, amynodonts) and even a higher diversity of extinct genera and species of horses, rhinos, and tapirs than are living today (Prothero and Schoch 1989, 2002). Each of these groups is easily fossilized and found in nearly all the Holarctic continents since the early Eocene, so they tend to have an excellent fossil record. Even though horse evolution has received the lion's share of the publicity, the record of rhinos, tapirs, and brontotheres is also excellent, and each deserves more frequent mention as exemplars of evolution to replace the overused examples of horse evolution.

The most striking thing about perissodactyl evolution is that we can see the very earliest stages of their diversification preserved in the fossil record. For many years, paleontologists have focused on the archaic hoofed mammal ("condylarth") group known as phenacodonts as the sister taxon of perissodactyls (Radinsky 1966, 1969; Thewissen and Domning 1992). These creatures were widespread around the Holarctic region of Eurasia and North America in the Paleocene and early Eocene and do indeed share many characters in common with perissodactyls. Phenacodonts, in turn, provide a link between perissodactyls and the most primitive clades of ungulates (Prothero et al. 1988). Moving even closer to true perissodactyls, we have the late Paleocene Chinese fossil known as Radinskya, which is a close sister group to almost all the earliest perissodactyls (McKenna et al. 1989). Known from a partial skull and a few other fragments, its

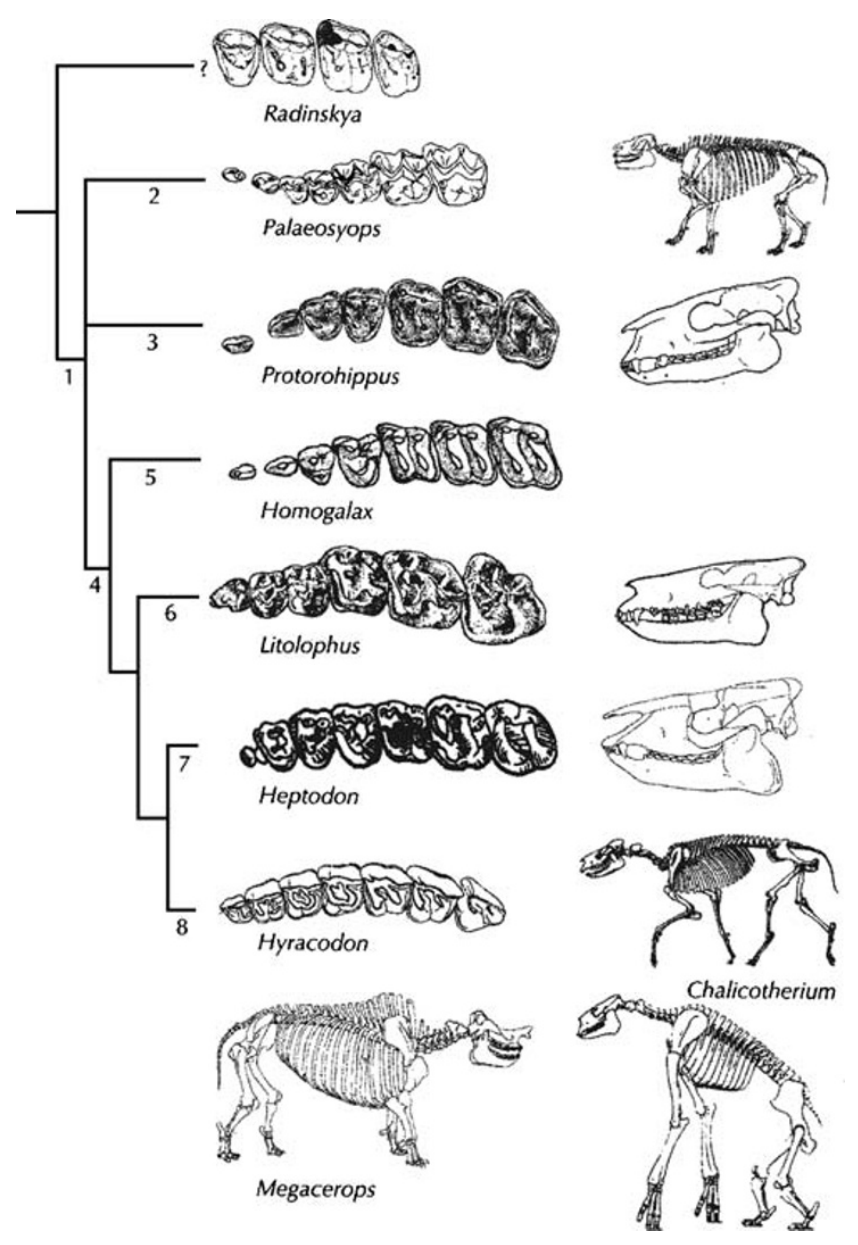

Fig. 1 The evolutionary radiation of perissodactyls, showing the major branches of the horses, rhinos, tapirs, chalicotheres, bronthotheres, and other extinct groups. As can be seen from the crown views of the upper left cheek teeth, the details of the crests and cusps are extremely similar between Radinskya, the early brontothere Palaeosyops, the primitive horse Protorohippus (long called "Hyracotherium"), the primitive moropomorph Homogalax, the chalicothere Litolophus, the tapiroid Heptodon, and the primitive rhinoceros Hyracodon. Shown next to the upper cheek teeth are typical skulls of horses, tapirs, and rhinos, emphasizing how similar they all looked in the early stages of perissodactyl evolution. The numbered branching points are as follows: 1 Perissodactyla, 2 Titanotheriomorpha, 3 Hippomorpha, 4 Moropomorpha, 5 Isectolophidae, 6 Chalicotheroiodiea, 7 Tapiroidea, 8 Rhinocerotoidea (phylogeny after Prothero and Schoch 1989; diagram after Kemp (2005), Fig. 7.19, p. 261; used by permission) 
teeth are more primitive than any bona fide perissodactyl, yet it shows some derived characters that make it a good sister taxon to that order. However, it is so primitive in most of its characters that McKenna et al. (1989) were unsure about its taxonomic assignment.

From these Asian Paleocene roots, there was a rapid diversification of perissodactyls in Europe and North America in the early Eocene. The earliest members of the horse, rhino, tapir, and brontothere lineages in North America are so similar to one another that only subtle features of the teeth and the skull allow us to tell them apart (Fig. 1). If you look at their fossils today, you would never guess that they would eventually diversify into such disparate groups as horses, rhinos, and tapirs, yet this is the evidence from the fossil record. This point was driven home to me while working on an undergraduate research project on early Eocene mammals from the Bighorn Basin of Wyoming. The specimens of the earliest horses (now called Protorohippus, according to Froehlich 2002) and the earliest tapiroids (Homogalax) were virtually identical, except that the Homogalax molars had slightly betterdeveloped cross-crests, a signature of the teeth of all later tapiroids. This incredible degree of similarity is also found in their skulls and skeletons (Fig. 1). In addition, the earliest relatives of the brontotheres look much like early horses and tapiroids. By the late early Eocene and middle Eocene, all of these lineages had diverged enough that tapiroids are much easier to distinguish from horses, and brontotheres are distinct from both. This is powerful evidence about how lineages can be traced back to common ancestors that are virtually indistinguishable from one another.

\section{Horse Sense}

Of these lineages, the story of horse evolution is most familiar. Ever since Marsh's work of the 1870s, it was clear that the earliest horses (formerly called "Eohippus" or "Hyracotherium," but now referable to Protorohippus and several other genera-Froehlich 2002) were beagle-sized creatures with simple low-crowned teeth, relatively short limbs and toes, and four toes on the hand and three toes on the hind foot. From this ancestry, horses are well documented to have become larger, longer-limbed, with a reduced number of side toes, and with higher-crowned teeth in most lineages (MacFadden 1992). By the 1920s, this simple idea of horse evolution was codified into diagrams that showed a single lineage of horse evolution from "Eohippus" to Equus (Fig. 2). This is the image that has become iconographic in nearly every textbook treatment of evolution since then.

One of the beauties of science (and particularly paleontology) is that it never stands still or rests on its laurels but continually builds and changes and revises its ideas as new material and data emerge. Since the 1920s, a huge number of additional horse fossils have been found, and many more species and genera described. By the time

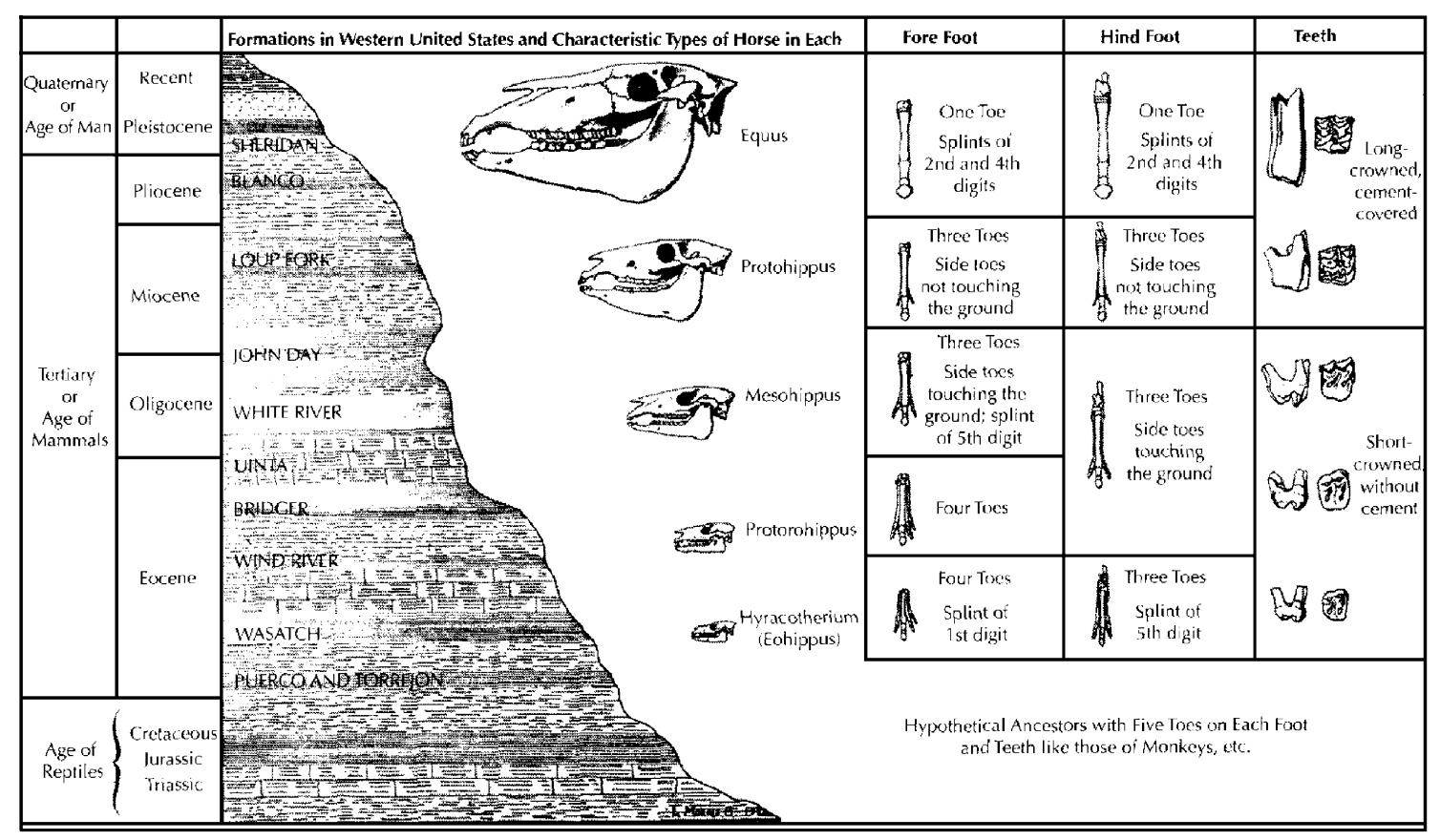

Fig. 2 The evolution of horses as it was portrayed a century ago when there were relatively few fossils. The overall trend through time is clear: larger size, longer limbs, reduction of side toes, development of a longer snout and larger brain, and especially the development of higher-crowned cheek teeth for eating gritty grasses. However, a century of further collecting has shown that horse evolution is a more complicated, bushy branching tree, rather than this oversimplified linear sequence (after Matthew 1926) 
of Simpson's (1951) book on horses, it was clear that their evolution was much more bushy and branching than the old diagrams suggested, and the work of the late twentieth century only added to the bushiness of their family tree (Fig. 3). In addition, studies of individual parts of this bush show surprising things about their diversity. For example, the classic "gradual" transition from Mesohippus to Miohippus was actually a bushy branching event, with as many as three species of Mesohippus and two of Miohippus occurring in the same late Eocene beds of Lusk, Wyoming, at exactly the same level (Prothero and Shubin 1989). Multiple species of horses were also documented from the same beds in the early Eocene (Froehlich 2002), and there were 12 different species of horses in the Railroad Quarry $A$ in the upper Miocene Valentine Formation of Nebraska. Thus, we have begun to appreciate that horse evolution is extremely bushy and branching, in contrast to the oversimplified "single lineage" models of a century ago.
One would think an improving record of horse evolution should impress creationists with all the new data. Instead, they quote old ideas out of context to deny that horse evolution occurred at all, or use outdated quotations about the replacement of the simplistic linear model with the complex bushy model to deny the reality of horse evolution (Gish 1995: 189-197; Wells 2000:195-207). Others like Sarfati (2002: 132-133) claim that all these fossil horses are within the range of variation of modern horses. Clearly, he has never actually looked at the fossils, since primitive horses like Protorohippus do not even remotely resemble the smallest modern ponies of the genus Equus. Every single comment on horse evolution from the creationists' literature betrays their complete lack of any firsthand knowledge of horse anatomy or fossils and shows that they cannot tell one bone from another. Instead, they criticize scientists for changing our ideas about horse evolution as we learned more from more and better fossils. Maybe this
Fig. 3 A modern view of horse evolution, emphasizing the bushy branching nature of their history, as many more fossils have been found and new species named. However, the overall trends toward highercrowned teeth (shown by the symbols for browsing leaves or grazing grasses), larger size, longer limbs, and reduction of side toes are still true (after Prothero 1994)

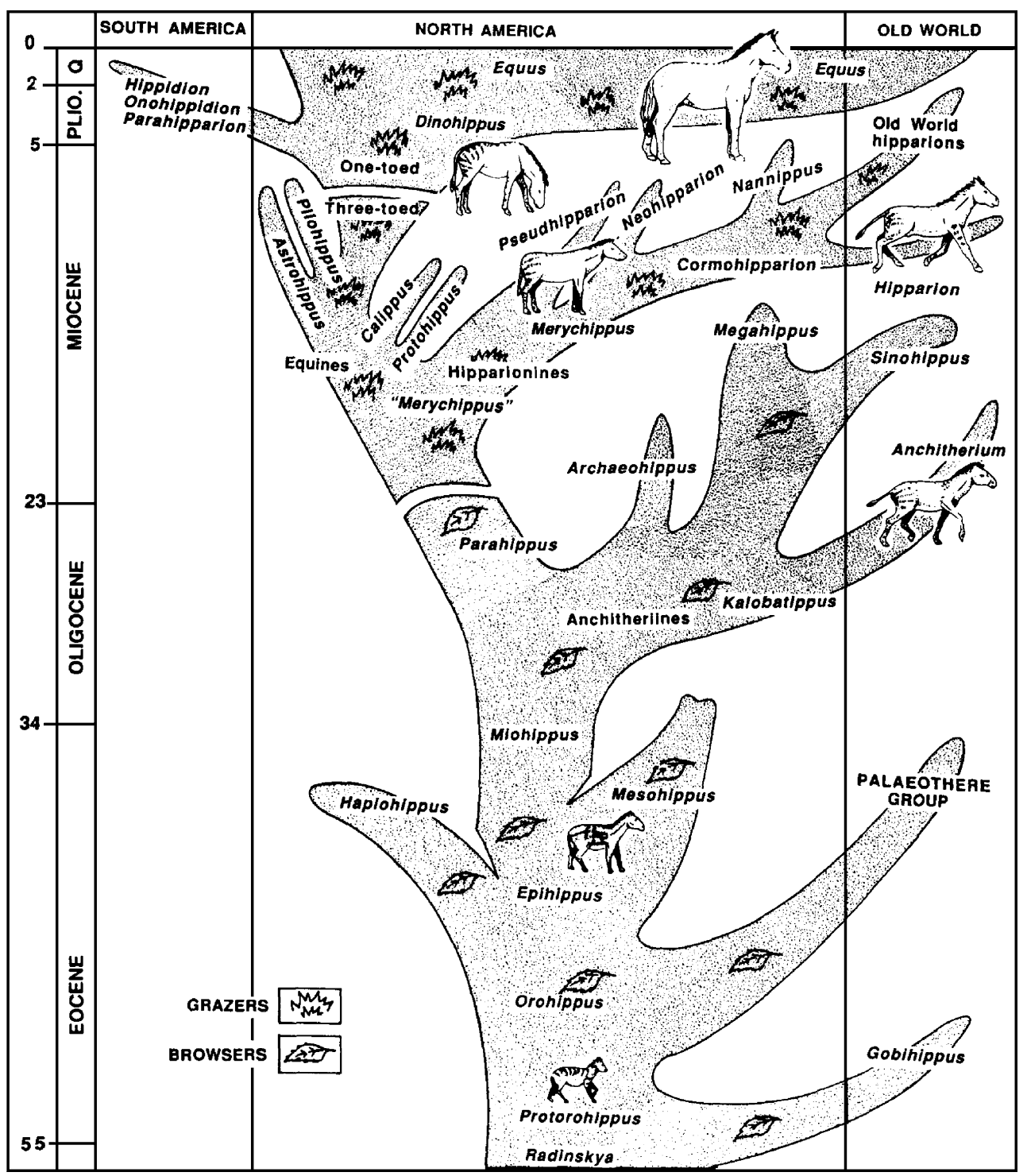


makes sense in their mindset of unchanging truths, but in the real world (and in science), more data are better, and change is good when the data demand it!

Rhinos Without Horns, Tapirs Without Snouts

If the evolution of horses were not enough, we now have excellent examples of the evolution of rhinos, tapirs, and brontotheres to add to the total evidence. My particular favorite is the evolution of the rhinoceroses, which I have studied for over 30 years (Prothero et al. 1986, 1989; Prothero 1998, 2005). The earliest rhino relatives like Hyrachyus are barely distinguishable from contemporary tapiroids (Fig. 4) in the early middle Eocene. By the late Eocene, they had diversified into three branches: the hippolike amynodonts, the long-legged running hyracodonts, and the true rhinoceroses, family Rhinocerotidae. Each family shows considerable diversification and evolution, with the hyracodonts evolving into the gigantic indricothere Paraceratherium (formerly called Baluchitherium or
Indricotherium), the largest land mammal that ever lived. It was a hornless rhino from the Oligocene of Asia that reached 7 meters tall at the shoulder and weighed at least 20 tons, larger than any elephant. Yet despite its huge size, it retained the relatively long slender limbs and toes of its hyracodont ancestry and did not develop the stubby graviportal toes seen in elephants and larger dinosaurs. The living family Rhinocerotidae also shows an incredible array of diverse body forms and interesting evolutionary patterns. Most extinct rhinos were hornless, since they do not show the roughened area on the top of the skull to which the horn (made out of compacted hairs) attached. Others exhibited many different horn combinations (single nasal horn, paired nasal horns, two tandem horns, single frontal horn), four independent episodes of dwarfing, independent development of high-crowned teeth in lineages adapted to grazing, and at least three instances of rhino lineages developing into shortlegged, barrel-chested hippo-like forms. Indeed, the evolution of rhinoceroses is fully as interesting and complex as the story of the horses, but has been underappreciated and
Fig. 4 The evolutionary history of North American rhinoceroses. In the Eocene, they branched into three families, the hippolike amynodonts, the longlegged running hyracodonts, and the living family Rhinocerotidae. During their evolution, they varied not only in body size and limb and skeletal proportions but also in the number and position of horns (or lack of horns), the details of their teeth, and many other features (after Prothero 2005)

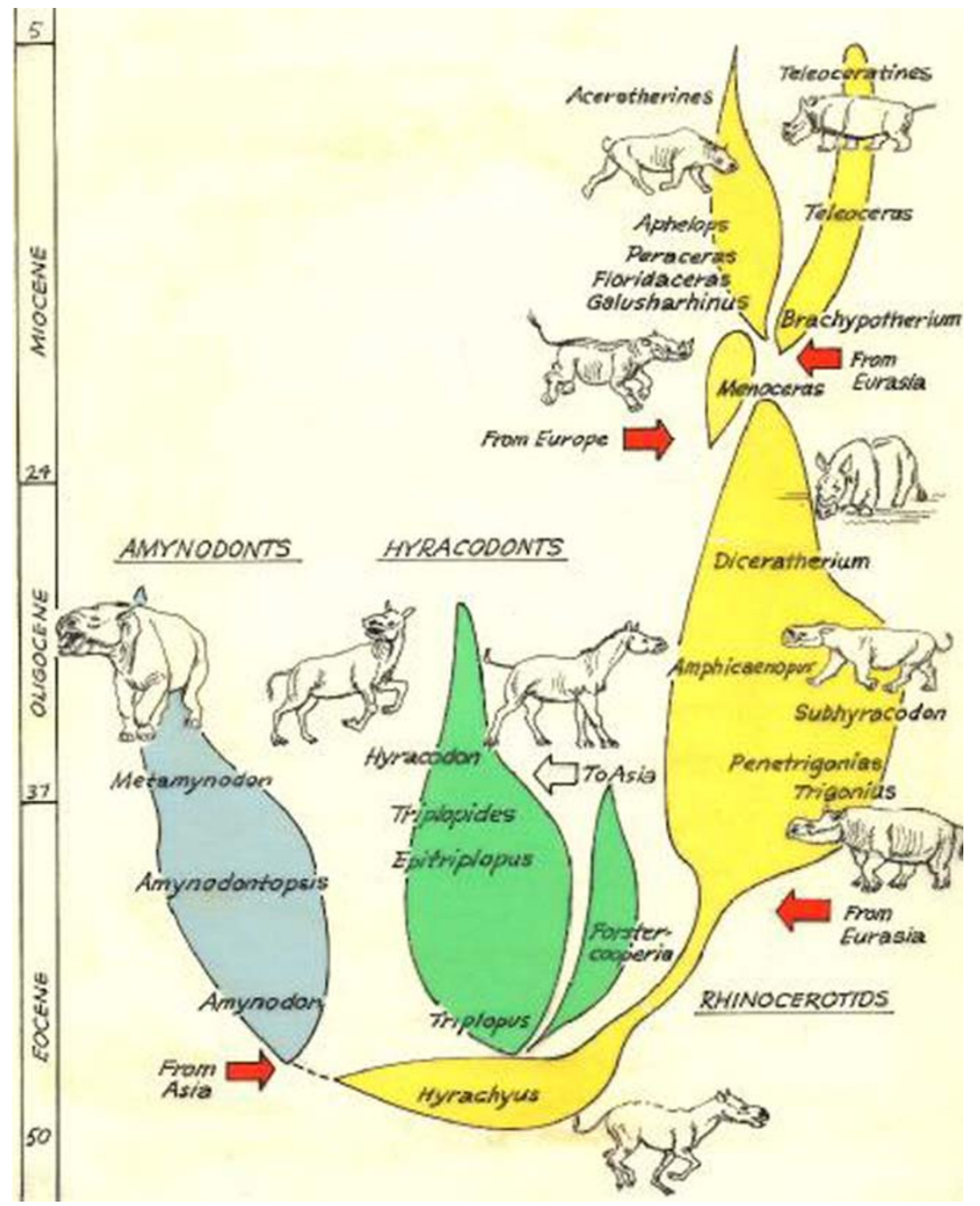


underpublicized because it was harder to simplify into the "linear" model once applied to horses (e.g., Fig. 2) and also because until recently, rhino systematics were so confused and outdated that nothing could be done with them (Prothero 2005).

Closely related to rhinos are the tapirs and their kin, including the chalicotheres. We have already seen that the earliest tapiroid, Homogalax, is barely different from the earliest horse (Fig. 1). From this ancestry, tapiroids rapidly developed the specialized molars with two strong crosscrests for chopping up their leafy diet and the retracted nasal bones that were the attachment area for their prominent proboscis (Fig. 5). The continual transformation of their teeth and skulls can be seen throughout their evolution, so that although Homogalax bears only the tiniest resemblance to the modern tapir, it can be linked with numerous transitional fossils that show every step in their evolution (Fig. 5).

\section{Thunder Beasts}

Extinct perissodactyls provide many good examples of evolutionary transitions as well. The brontotheres ("thunder beasts") or titanotheres (Fig. 6) were long portrayed by the paleontologist Henry Fairfield Osborn (1929) as a continuous gradual lineage that got larger and eventually developed huge paired battering-ram horns on their noses. This outdated notion has been completely revised with modern taxonomy (Mihlbachler 2008), but the general trends are still apparent on their bushy family tree (Fig. 7). Brontotheres evolved from creatures such as Lambdotherium that looked much like contemporaneous early Eocene horses and tapiroids, but with tiny differences in their teeth. By the middle Eocene, brontotheres had become much more diverse in size and anatomy, with multiple lineages coexisting at the same time. In the Chadronian (late Eocene, formerly thought to be early
Fig. 5 Evolution of the tapirs from primitive forms with skulls much like Eocene horses and rhinoceroses through progressively more specialized forms which have a deeper retraction of the nasal notch, indicating a larger proboscis (modified from Prothero and Schoch 2002)

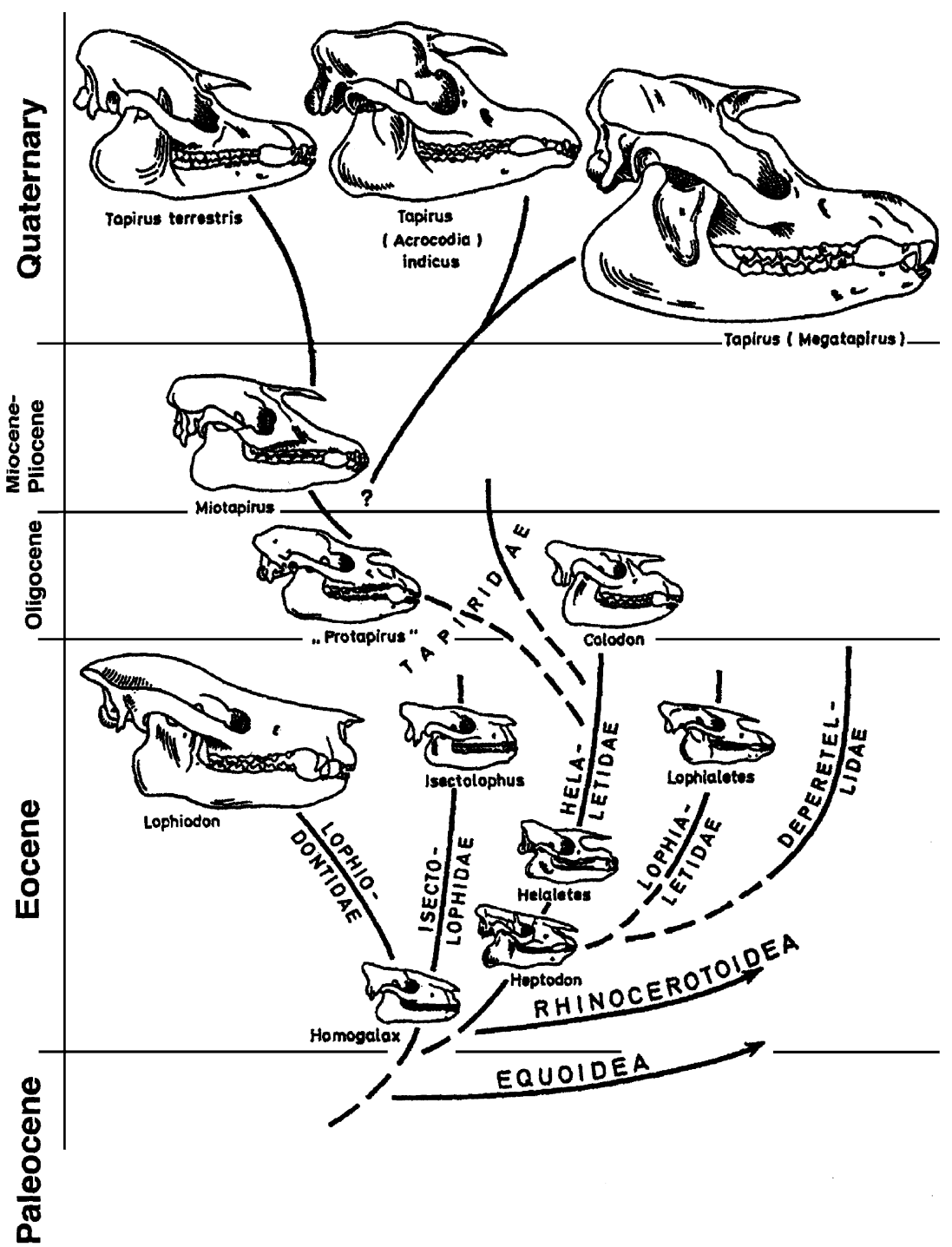




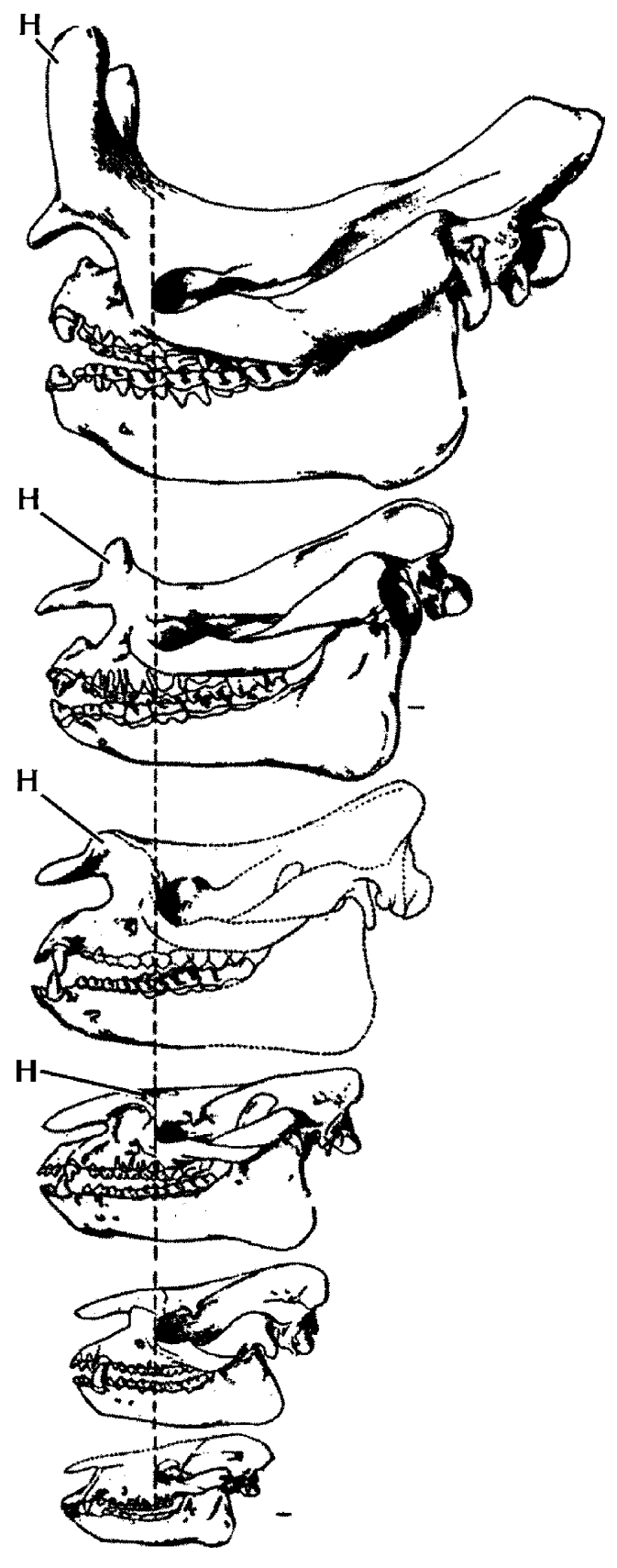

Fig. 6 Conventional linear view of brontothere evolution through the Eocene from primitive forms like Palaeosyops that are barely distinguishable from contemporary horses through larger and larger forms that eventually developed two blunt horns on their noses (after Osborn 1929)

Oligocene), they reached the culmination of their evolution, becoming elephant-sized beasts whose impressive blunt battering rams on their noses have invited so much speculation. Although we now reject Osborn's (1929) simplistic linear model of evolution and bad taxonomy (Fig. 6), the overall trends in brontothere evolution are still real, even as their taxonomy changed and the phylogeny became more bushy and branching.

\section{Cloven Hooves}

The Artiodactyls

The largest group of ungulates (living and fossil) is the order Artiodactyla. With over 190 living species and at least ten times as many fossil species, they are the most diverse and abundant large herbivores on the planet. They include pigs, peccaries, hippos, camels, deer, pronghorns, giraffes, sheep, goats, cattle, and antelopes. In addition, there are many more extinct families that are familiar only to paleontologists, including the primitive diacodexeids, the pig-like entelodonts, the ubiquitous oreodonts, the bizarrely horned protoceratids and dromomerycines, and many others. Nearly all domesticated animals that we eat (cattle, pigs, sheep, goats) or get milk from (cattle, goats) or use for leather or wool (cattle, sheep) are artiodactyls. As such, they are much more familiar to us, even though a lot remains to be learned about their evolution.

Artiodactyls are defined not just by their "cloven hooves" (even number of toes, two or four), but also by the symmetry of their feet. They have a paraxonic foot, with the axis of symmetry running between digits III and IV (middle finger and the ring finger, or third toe/fourth toe). Even more striking is the universal hallmark of all artiodactyls, the "double-pulley" astragalus in their ankles, which allows them to have very flexible fore and aft motions of their foot (but prevents lateral rotation). Artiodactyls have many other distinctive characteristics in their skulls and skeletons, especially in the unique crescent-shaped crests (selenodonty) that many groups independently evolved in their cheek teeth.

The origin and early evolution of artiodactyls is just now becoming better known as new discoveries are made (Prothero and Foss 2007). The sister taxon of artiodactyls is still controversial (Prothero et al. 1988; Theodor et al. 2005; Rose 2006; Prothero and Foss 2007). Various candidates have been proposed, ranging from archaic ungulates like the huge predatory mesonychids to the coatimundi-like arctocyonid ungulates such as Chriacus. In any case, the evidence suggests that artiodactyls are one of the first groups to branch off from the rest of the hoofed mammals. By the early Eocene, very primitive artiodactyls known as diacodexeids or dichobunids were widespread across Eurasia and North America. To the casual viewer, these creatures (about the size of a small dog) would look like a small musk deer or even rabbit-like, since they had long slender hind limbs for leaping. However, a closer look at the teeth and ankles and feet shows that they have all the hallmarks of artiodactyls, especially in the double-pulley astragalus and paraxonic foot.

By the middle Eocene, these diacodexeids had been replaced by a huge radiation of archaic artiodactyl groups in 


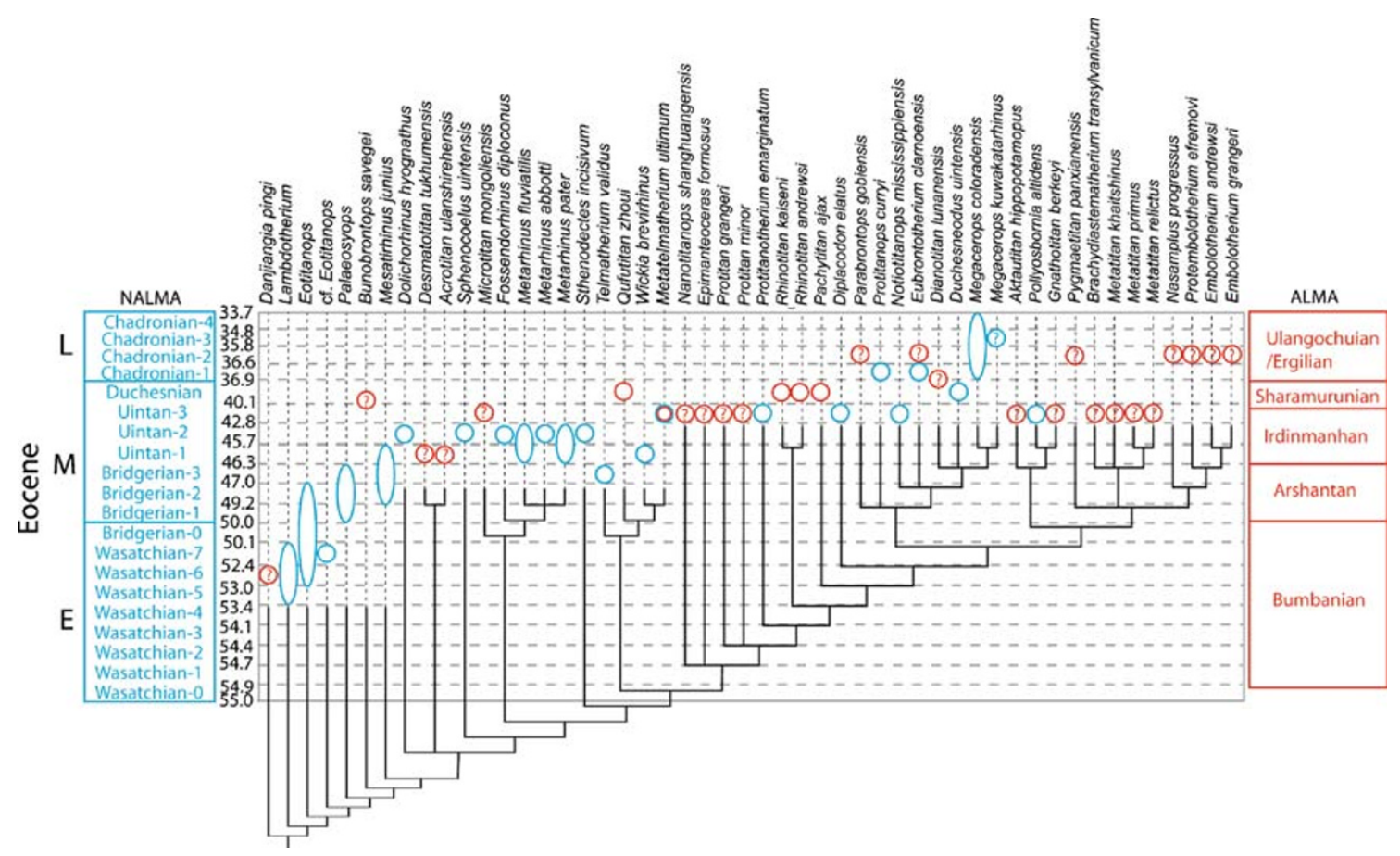

Fig. 7 A modern view of brontothere evolution showing the more branched bushy pattern of species through time, based on the work of Mihlbachler (2008; diagram courtesy of M. Mihlbachler)

North America and Asia (Gazin 1955; Stucky 1998; chapters in Prothero and Foss 2007), nearly all of which are now extinct. Each of these groups is only slightly more advanced than their primitive sister groups, yet there are already trends toward the low-crowned grinding teeth (bunodonty) in the lineages that led to pigs, peccaries, and hippos (numerous genera from the middle-late Eocene of China and Thailand-Harris and Liu 2007). There were still others that were specialized in the direction of ruminants (Archaeomeryx from the middle Eocene of Mongolia-Metais and Vislobokova 2007) and camels (middle Eocene North American forms such as oromerycids and the camel Poebrodon). Europe had its own unique endemic radiation of seven artiodactyl families that evolved in isolation when Europe was a flooded archipelago (Erfurt and Metais 2007). There are so many of these excellent examples of evolution within these families that an entire book (e.g., Prothero and Foss 2007) is required to cover the topic. For the purposes of this essay, however, we will examine two that are particularly striking: the camels and the giraffes.

\section{Camels Without Humps}

Most of us think of camels as humped creatures of the African and Asian deserts, but the two Old World camelids (the one-humped dromedary and two-humped Bactrian camels) are actually exceptions to the general trend. Most of camelid evolution took place in North America, with only later migrations to Eurasia about 7 million years ago and to South America about 3 million years ago. The latter migration event gave rise to the living llamas, alpacas, vicuñas, and guanacos, which can be thought of as more typical of the humpless camels found in the fossil record. Based on their sister-group relationships, there is no reason to think that extinct camels had humps; it is likely that it is a unique feature of the desert-dwelling Old World camelids. In their North American homeland, camels evolved from the tiny but hypsodont Poebrodon of the middle Eocene to the larger sheep-sized late Eocene-Oligocene Poebrotherium (Prothero 1996). Camels then diversified into many different families (Fig. 8), including the gazelle-like stenomylines, which had enormously hypsodont teeth, the long-snouted floridatragulines, the short-legged miolabines, and the longnecked aepycameline and "giraffe camels" such as Oxydactylus (Honey et al. 1998). Some were even bigger than giraffes, such as Titanotylopus and Gigantocamelus. Many camels apparently performed the roles of gazelles or antelopes or giraffes in the North American savannas during the Miocene, since those African groups never reached North America at that time. Thus, the evolution of the camels is just as amazingly branching and bushy as the example of horse or rhino evolution. Unfortunately, the basic systematics of the group has not yet been fully documented yet (although Jim Honey and I are currently 
Fig. 8 The family tree of camels, showing the great diversity of forms, from small primitive deer-like creatures to the gazelle-like stenomylines, the short-legged protolabines and miolabines, the long-legged long-necked "giraffe camels," and the modern humpless South American camels (alpaca, llama, vicuña, guanaco), which are more typical of the whole family. Only the living African dromedary and two-humped Asian Bactrian camels have humps (after Prothero 1994)

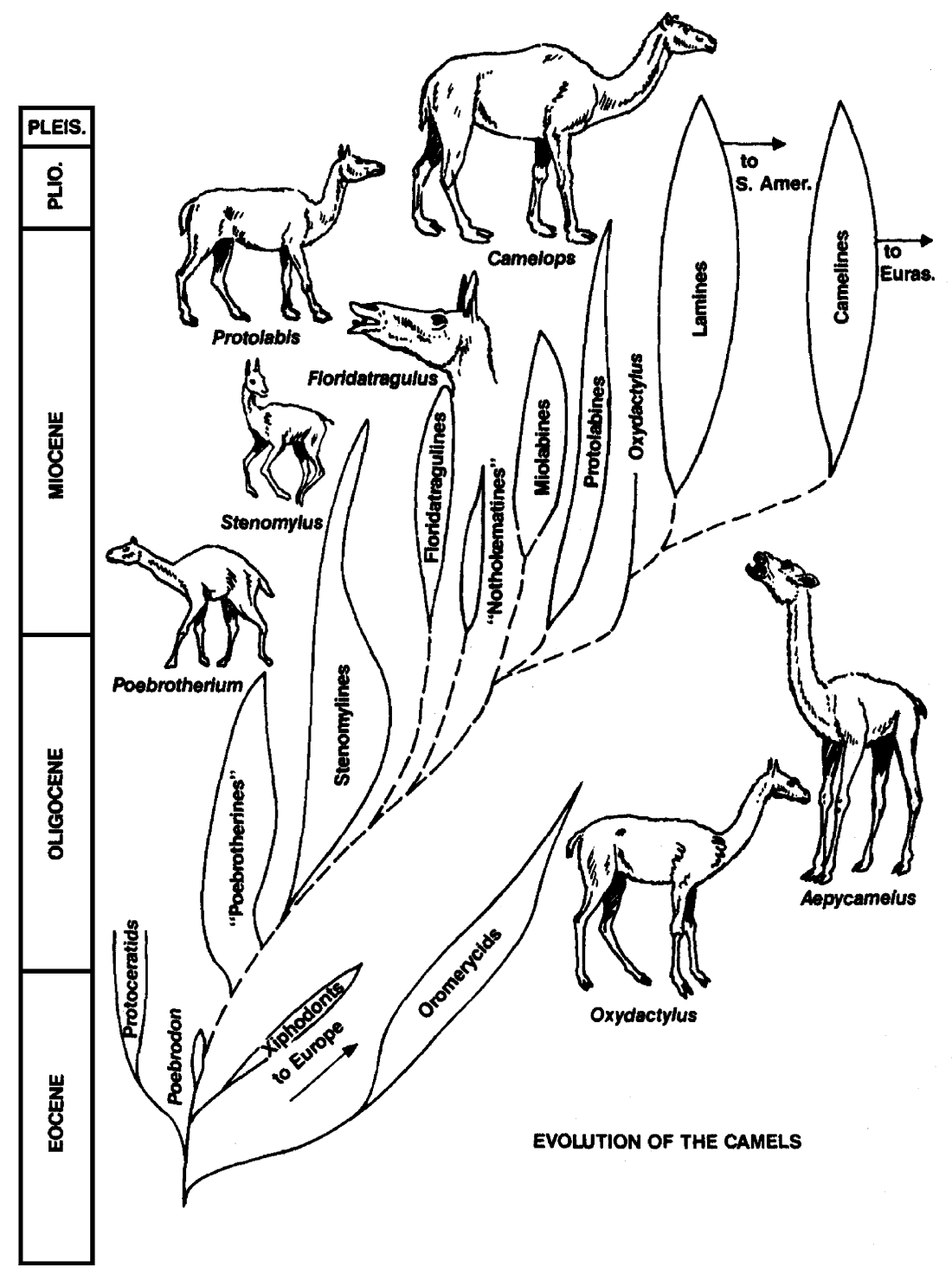

working on this as a long-term project); the latest summary can be found in Honey et al. (1998).

Although camel phylogeny was bushy and branching, we can still observe some overall trends in their evolution (Fig. 9). From their sister group, the oromerycids like Protylopus, to the earliest camelids like Poebrotherium, to the larger more advanced camels like Procamelus, we can document a striking change in size, crown height of the teeth, reduction in side toes, and eventually fusion of the metacarpals and metatarsals into a cannon bone. There was also an elongation of the snout and development of gaps, or diastemata, between the anterior teeth. This example shows that the earliest camels look nothing like modern camels and that we have all the transitional fossils that link the earliest camels with their living descendants and from the camelids back to the oromerycids and hence back to more primitive sister taxa among the artiodactyls.

\section{Short-Necked Giraffes}

Our second example from the artiodactyls is the giraffids. Creationists often scoff at the notion that there are fossils that show how the giraffes evolved, but they could not be more mistaken. In fact, the giraffids have an excellent fossil record, although nearly all giraffes (both extinct and living) are short-necked, much like the modern okapi. Only the living genus Giraffa has the long neck that we consider typical of the group. All the rest of the giraffids (Fig. 10) were not only short-necked but sported a wide variety of cranial appendages. Some, like Sivatherium, were stocky moose-like creatures with broad palmate horns somewhat like those of a moose. Others, like Climacoceras, looked more like deer or antelopes. Despite these superficial convergences, they all show the characteristic hallmarks of giraffids in their teeth, skulls, and skeletons. 


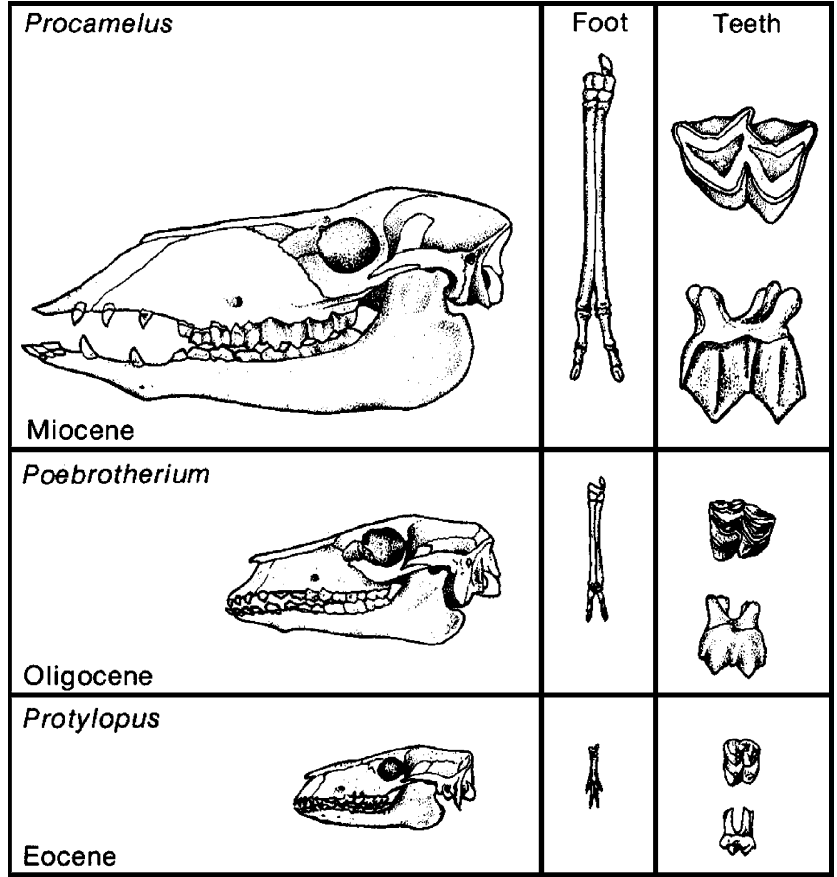

Fig. 9 Evolutionary trends within the camels, from the tiny oromerycid Protylopus through the Oligocene camel Poebrotherium through more advanced Procamelus. Although their history is not a straight line of evolution but a bushy branched pattern, there are trends toward larger body size, loss of the front teeth, longer snouts and larger eyes, longer legs and toes (reducing to just two toes fused together), and higher-crowned cheek teeth (after Scott 1913)
Most of these taxa are known from skulls and jaws and a few from skeletons, but the neck vertebrae are not often preserved. However, Nikos Solounias (2007, personal communication) is currently publishing a description of a new fossil of the giraffid Bohlinia that preserves a neck that is intermediate in length between Giraffa and the okapi (Fig. 11). Thus, we do know how the giraffe got its long neck, and we have the transitional fossils to show how and when it occurred! Once again, the fossil record has provided a specimen whose very existence the creationists have long denied.

\section{The Tethytheres}

\section{Elephants and Their Kin}

Both molecular and paleontological evidence agree that artiodactyls and perissodactyls are a natural group of ungulates. However, when it comes to a third major hoofed mammal clade, the tethytheres (elephants, sirenians, and their kin), there is a conflict between molecular evidence which places them in the Afrotheria (Springer et al. 2004; Murphy et al. 2001) and the morphological and paleontological evidence that unites them with ungulates (Novacek 1986, 1992; Novacek and Wyss 1986; Novacek et al. 1988; Prothero et al. 1988; Prothero 1993; Gheerbrant et al. 2005). We will not discuss this issue further here, because numerous laboratories and paleontologists are working to
Fig. 10 Evolution of the giraffe family. The modern okapi is more typical of the group, with its short neck and relatively short horns or "ossicones." Some fossil giraffids, however, had very unusual branching and flaring cranial appendages. Only the lineage of the modern giraffe evolved a long neck (after Prothero 1994)

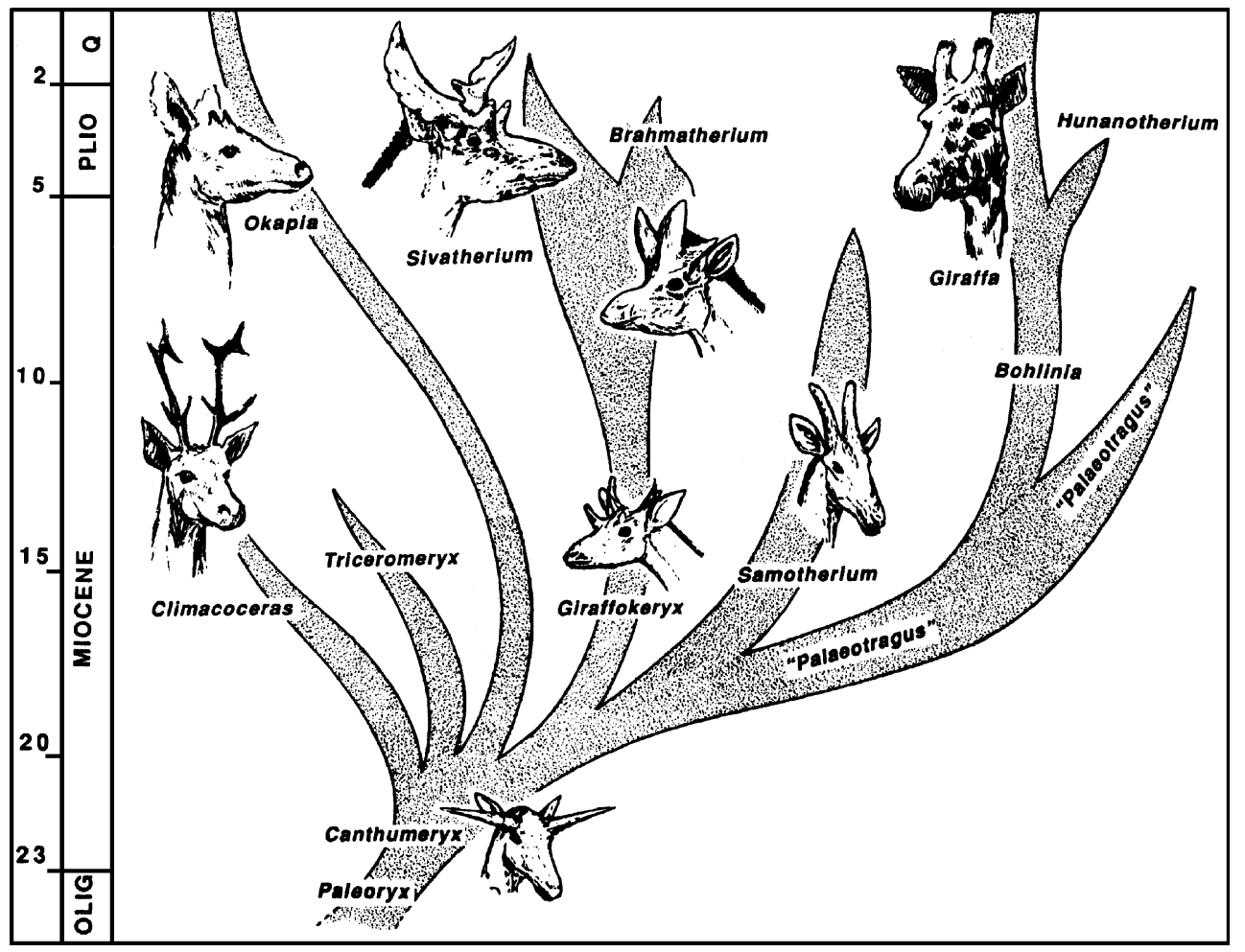




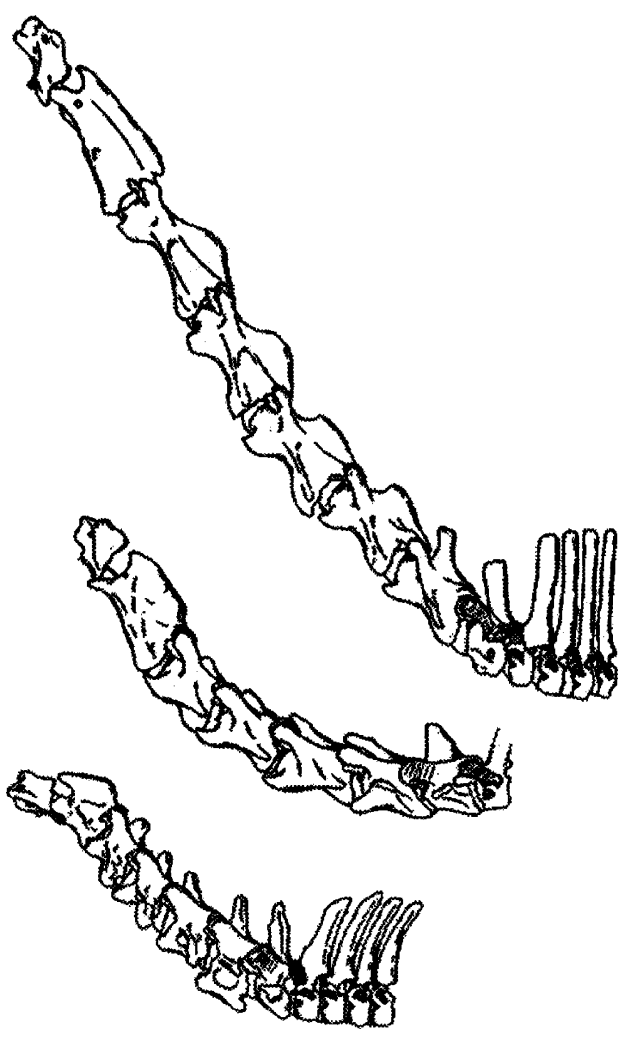

Fig. 11 Neck vertebrae of a recently discovered fossil giraffid Bohlinia that is intermediate in length between those of primitive giraffids (Okapia, bottom) and the modern long-necked species (Giraffa, top). This amazing discovery is a true "missing link" between okapis and the long-necked modern species (drawing courtesy of N. Solounias)

resolve the conflict. Many of primitive tethytheres had hooves, so we will treat them as hoofed mammals in an ecological sense, even if it is not clear that they are part of the Ungulata.

\section{Elephants Without Trunks}

The Proboscidea, or the order of elephants and their extinct relatives, have an outstanding fossil record (Shoshani and Tassy 1996), since they are large-bodied heavy-boned animals that fossilize well. The details of their systematics are still not fully worked out (Lambert and Shoshani 1998), but many of the broader trends are well documented. The earliest proboscidean in the fossil record is known as Phosphatherium; it comes from the late Paleocene of Morocco (Gheerbrant et al. 1996). Although it consists of a partial skull, the teeth already have the classic mastodont pattern. By the early Eocene, we have Numidotherium from Algeria (Mahboubi et al. 1984), which shows the high forehead and small tusks characteristic of mastodonts and the beginning of retracted nasal bones, suggesting a short proboscis. By the late Eocene and Oligocene, we have the well-known Moeritherium, which looked more like a large tapir or pygmy hippo than an elephant (Fig. 12). Nevertheless, the skull shows evidence of a short proboscis, short tusks in the upper and lower jaws, teeth typical of primitive mastodonts, and many details in the rest of the skull that unquestionably link it with the Proboscidea.

From Moeritherium, there was a tremendous radiation of mastodonts and mammoths in the Oligocene and Miocene (Fig. 13), including lineages with shovel-like lower tusks (the amebelodonts), some with downturned lower tusks (the deinotheres), some with very long straight tusks (the anancines) or four long straight tusks (the stegotetrabelodonts), plus the lineage of the American mastodon (the mammutids), and the lineages that became the mammoths and modern elephants. All of these can be traced back to primitive gomphotheres of the Oligocene and Miocene, which had short trunks and tusks, but were otherwise unspecialized. The gomphotheres, in turn, can be traced back to primitive forms from the Egyptian Oligocene Fayûm beds, including Phiomia and Palaeomastodon. Once again, the phylogeny is bushy and branching, although it can be summarized in terms of its general

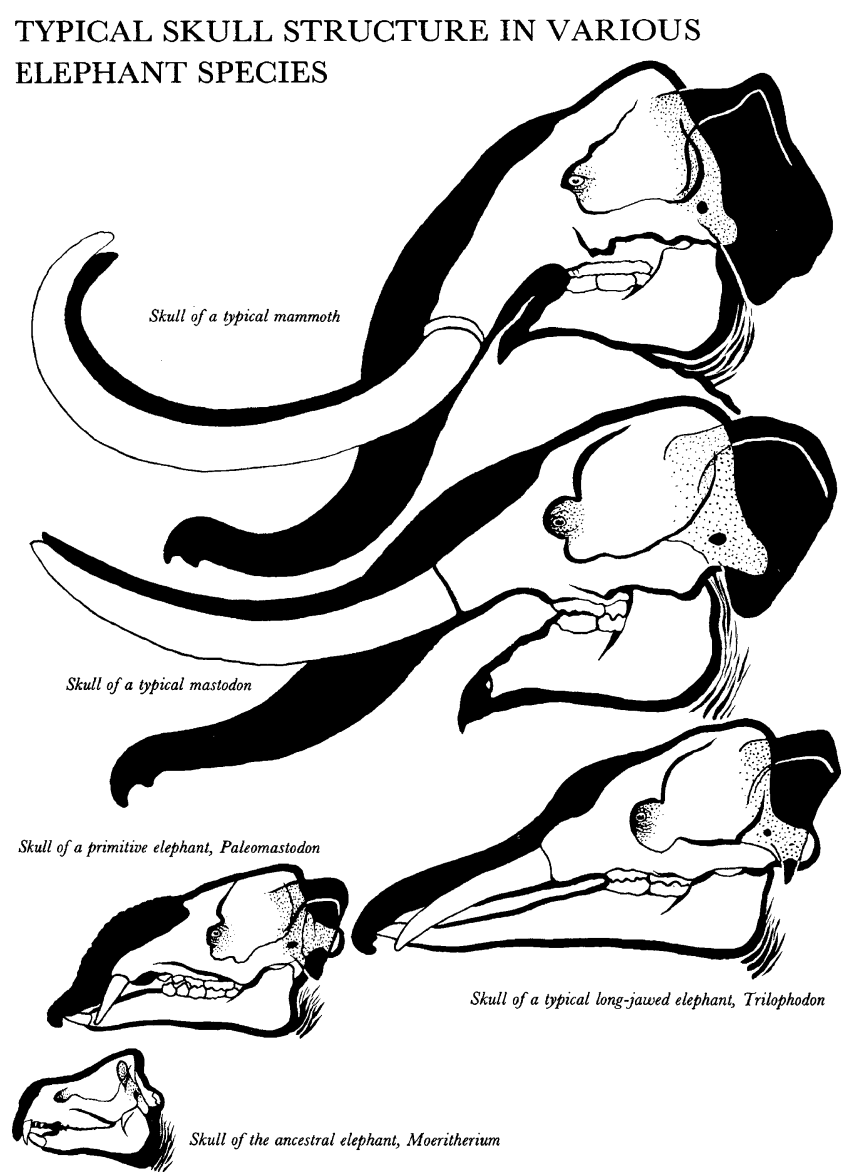

Fig. 12 Details of the evolution of the skull, tusks, and trunk of proboscideans, from the pygmy hippo-like Moeritherium through mastodonts with longer tusks and trunks to mammoths (after Scheele 1955) 
Fig. 13 Evolutionary history of the elephants and their kin (Proboscidea), starting with pygmy hippo-like forms like Moeritherium with no trunk or tusks, through mastodonts with short trunks and tusks, and concluding with the huge mammoths and the two living species. Early in their history, the other tethytheres branched off from the Proboscidea.

These include the manatees, order Sirenia, the extinct desmostylians, and the extinct horned arsinotheres (from Prothero 1994)

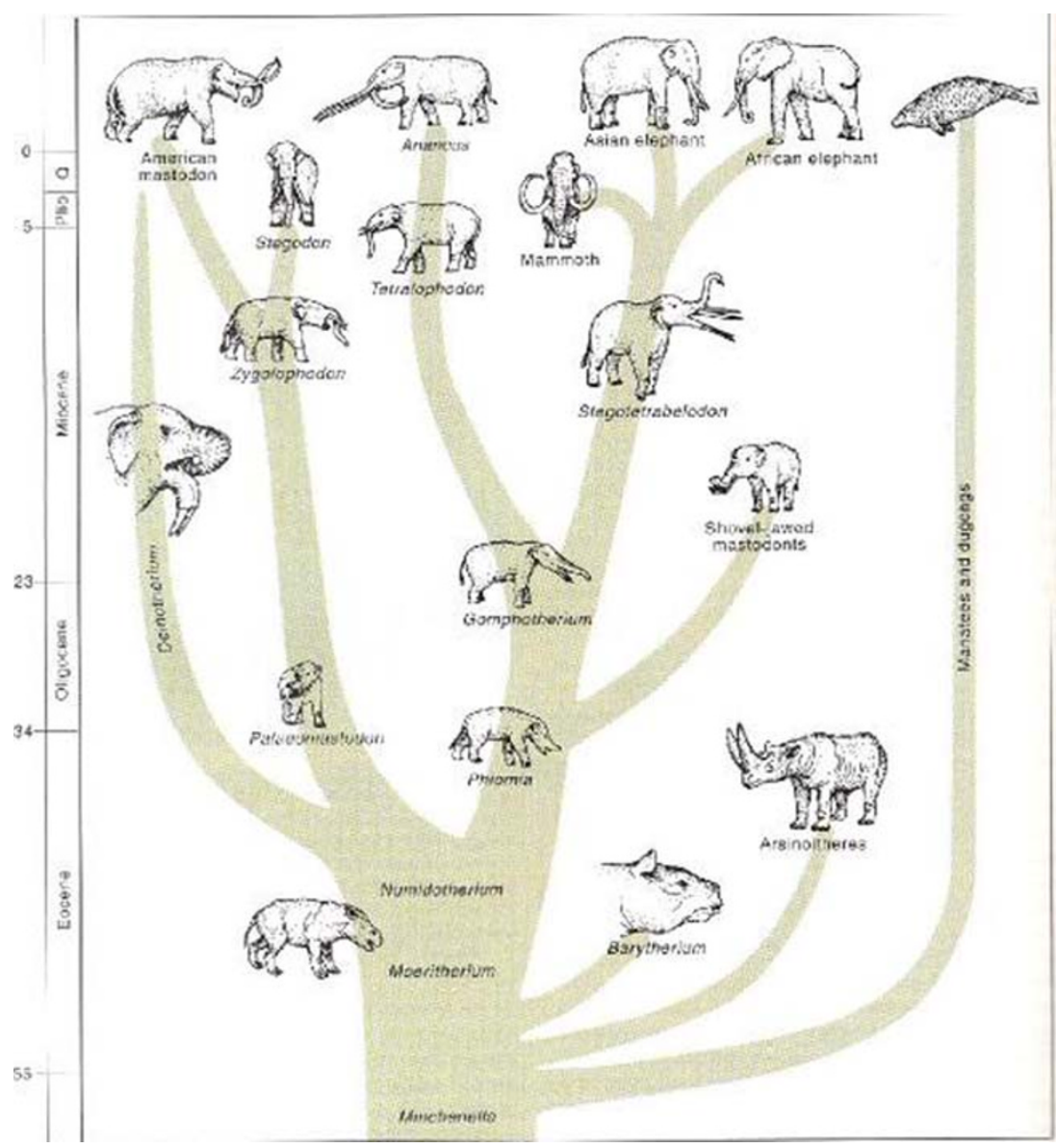

trends (Fig. 12): gradual retraction of the nasal opening, indicating a larger and longer proboscis and eventually a true trunk; elongation of the upper and lower incisors to form a variety of tusk shapes and combinations; specialization of the teeth from simple bunodont pig-like teeth to the cross-crested lophodont teeth of many mastodonts, to the highly specialized grinding teeth of elephants and mammoths; and many other trends. A creationist might take a superficial look at Moeritherium and assign it to the "hippo kind," but we have all the transitional fossils (and the anatomical evidence) to trace it right up to modern elephants.

\section{Walking Manatees}

Finally, let us look at another order of mammals, the Sirenia or "sea cows" (the manatees and dugongs). Today, these peaceful aquatic creatures float in shallow tropical waters and graze on sea grass. They are fully aquatic, with two front flippers and no visible hind legs. For decades, their relationships to the rest of the mammals were unknown until McKenna (1975) showed that they are the sister taxon of the Proboscidea and part of a group he called the Tethytheria. Subsequent work has found a huge number of highly specialized features that confirm this hunch, so it is now a well-established notion. In the past decade, the monophyly of the Tethytheria was also confirmed by later molecular analysis. However, most sirenian fossils are incomplete, usually consisting of the distinctive extremely dense bone of their ribs (used for ballast) or occasional skulls and teeth. Then Daryl Domning (2001) described an

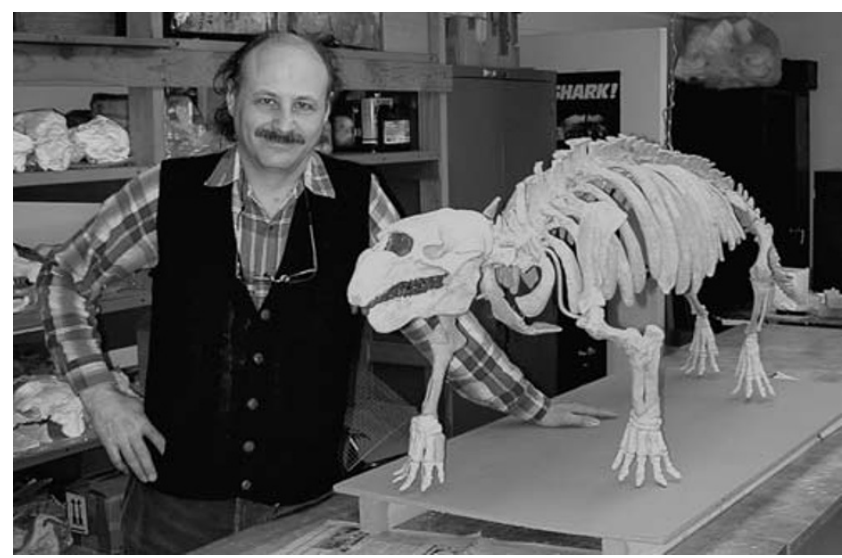

Fig. 14 The mounted skeleton of Pezosiren portelli, the sirenian with feet rather than flippers, next to Daryl Domning, who described and named it (photo courtesy of Dr. Raymond L. Bernor) 
amazing transitional fossil from the Eocene of Jamaica (Fig. 13). Known as Pezosiren portelli ("Portell's walking sirenian"), it has the characteristic skull and teeth of a sirenian and even the dense bones of the ribs so typical of the group. Yet this creature had four perfectly good legs complete with terrestrial hands and feet, not flippers as seen in the living sirenians (Fig. 14).

One could not ask for a better example of a transitional fossil! It closely parallels the intermediate pattern of locomotion seen in walking whales such as Ambulocetus (Thewissen, this volume). When creationists have addressed this discovery at all (on their websites; none of their books mention it yet), they show their complete ignorance of the basics of anatomy and paleontology. Their argument boils down to "if it has four legs and feet, it can't be a sirenian," even though the details of the teeth, skull, and even the ribs share the specializations unique to the entire order Sirenia. In short, they do not understand the basic notion of homology and analogy. They automatically define "sirenian" so it cannot have legs and feet, just as they deny that Ambulocetus is a whale that walked (even though its skull and teeth and many aspects of the skeleton are typical of archaeocete whales). This kind of mental straitjacket and getting out of a dilemma by defining it away might make them feel better, but it is no excuse for knowing their anatomy or fossils or getting the facts straight.

\section{Conclusions}

In short, the fossil record of hoofed mammals is full of transitional fossils and even longer transitional sequences that demonstrate the origins of nearly all the living ungulates and tethytheres from ancestors that looked almost completely unlike their descendants. We now have the fossils that show where the perissodactyls came from (phenacodonts, Radinskya) and that document the radiation of the earliest horses, tapirs, rhinos, and brontotheres when they were almost indistinguishable to the untrained eye (Fig. 1). We have the fossils that demonstrate the evolution of the horse family, the rhinoceroses, the tapirs, and the brontotheres, along with other examples not covered in this article. Their phylogenies are now much more bushy and branching, but otherwise, the general trends are the same that were observed over a century ago. Creationists attempt to discredit these examples by saying that our switch from an orthogenetic linear model of the 1920s to the modern bushy branching pattern somehow denies that this fossil evidence does show change through time, but this only reveals the creationists' lack of training in anatomy and paleontology. Likewise, we now have the fossils to document the early stages of the radiation of the artiodactyls and especially the bushy branching history of camels and giraffes, both of which lacked humps or long necks in their respective early histories. Finally, the fossil record of transitions within the Proboscidea is excellent, from pig- or tapir-like beasts like Moeritherium that creationists would never place in the "elephant kind" to a variety of mastodonts leading up to modern elephants. One of the best transitional fossils of all is Pezosiren portelli, a perfect intermediate form that shows how the aquatic manatees evolved from walking ancestors.

All of these examples are largely ignored by creationists, or when they do mention them, they use completely outdated arguments, quotes out of context, or simple lies and distortions that demonstrate the fact that creationists have no training in anatomy or paleontology and cannot tell one bone from another. In the most extreme cases, the creationists resort to semantic gyrations that define the problem away, so that if a fossil has terrestrial legs and feet, it cannot be a sirenian or a whale, even if every other aspect of the anatomy clearly indicates its phylogenetic affinities. Arguments such as this reveal the dogmatism and complete intellectual and scientific bankruptcy of creationists. If they really cared to find out whether there were transitional forms in the fossil record, they would stop quoting out of context from children's books or outdated secondary sources and obtain the proper anatomical and paleontological training to study the fossils themselves. Since they do not even bother to do this, their arguments are worthless.

Acknowledgments I thank Niles Eldredge for suggesting this volume and helping edit the proceedings and two anonymous reviewers for helpful comments on this article.

\section{References}

Domning DP. The earliest known fully quadrupedal sirenian. Nature. 2001;413:625-7. doi:10.1038/35098072.

Erfurt J, Metais G. Endemic European Paleogene Artiodactyls: Cebochoeridae, Choeropotamidae, Mixtotheriidae, Cainotheriidae, Anoplotheriidae, Xiphodontidae, and Amphimerycidae. In: Prothero DR, Foss SE, editors. The evolution of artiodactyls. Baltimore, MD: Johns Hopkins University Press; 2007. p. 59-84.

Froehlich DJ. Quo vadis Eohippus? The systematics and taxonomy of the early Eocene equids (Perissodactyla). Zool J Linn Soc Lond. 2002;134:141-256. doi:10.1046/j.1096-3642.2002.00005.x.

Gazin CL. A review of the upper Eocene Artiodactyla of North America. Smithson Misc Contrib. 1955;128:1-96.

Gheerbrant E, Sudre J, Cappetta H. A Palaeocene proboscidean from Morocco. Nature. 1996;383:68-71. doi:10.1038/383068a0.

Gheerbrant E, Domning DP, Tassy P. Paenungulata (Sirenia, Proboscidea, Hyracoidea, and relatives). In: Rose KD, Archibald JD, editors. The rise of placental mammals. Baltimore, MD: Johns Hopkins University Press; 2005. p. 84-105.

Gish D. Evolution, the fossils still say NO!. San Diego, CA: CreationLife; 1995. 
Harris JM, Liu LP. Superfamily Suoidea. In: Prothero DR, Foss SE, editors. The evolution of artiodactyls. Baltimore, MD: Johns Hopkins University Press; 2007. p. 130-50.

Honey J, Harrison JA, Prothero DR, Stevens MS. Camelidae. In: Janis C, Scott KM, Jacobs LL, editors. Evolution of tertiary mammals of North America. Cambridge, MA: Cambridge University Press; 1998. p. 439-62.

Kemp TS. The origin and evolution of mammals. Oxford: Oxford University Press; 2005.

Lambert WD, Shoshani J. Proboscidea. In: Janis C, Scott KM, Jacobs LL, editors. Evolution of tertiary mammals of North America. Cambridge, MA: Cambridge University Press; 1998. p. 606-22.

MacFadden BJ. Fossil horses. Cambridge, MA: Cambridge University Press; 1992.

Mahboubi M, Ameur R, Crochet JY, Jaeger JJ. Earliest known proboscidean from early Eocene of North Africa. Nature. 1984;308:543-4. doi:10.1038/308543a0.

Matthew WD. The evolution of the horse: a record and its interpretation. Q Rev Biol. 1926;1:139-85.

McKenna MC. Toward a phylogenetic classification of the Mammalia. In: Luckett WP, Szalay FS, editors. Phylogeny of the primates: a multidisciplinary approach. New York: Plenum; 1975. p. 21-46.

McKenna MC, Chow MC, Ting SY, Luo ZX. Radinskya yupingae, a perissodactyl-like mammal from the late Paleocene of China. In: Prothero DR, Schoch RM, editors. The evolution of perissodactyls. New York, NY: Oxford University Press; 1989. p. 24-36.

Metais G, Vislobokova I. Basal ruminants. In: Prothero DR, Foss SE, editors. The evolution of artiodactyls. Baltimore, MD: Johns Hopkins University Press; 2007. p. 189-212.

Mihlbachler MC. Species taxonomy, phylogeny, and biogeography of the Brontotheriidae (Mammalia: Perissodactyla). Bull Am Mus Nat Hist. 2008;311:1-473. doi:10.1206/0003-0090(2008)501[1: STPABO]2.0.CO;2.

Murphy WJ, Eizirik E, Johnson WE, Zhang YP, Ryder OA, O’Brien SJ. Molecular phylogenetics and the origin of placental mammals. Nature. 2001;409:614-8. doi:10.1038/35054550.

Novacek MJ. The skull of leptictid insectivorans and the higher-level relationships of eutherian mammals. Bull Am Mus Nat Hist. 1986;183:1-112.

Novacek MJ. Mammalian phylogeny: shaking the tree. Nature. 1992;356:121-5. doi:10.1038/356121a0.

Novacek MJ, Wyss AR. Higher-level relationships of recent eutherian orders: morphological evidence. Cladistics. 1986;2:257-87. doi:10.1111/j.1096-0031.1986.tb00463.x.

Novacek MJ, Wyss AR, McKenna MC. The major groups of eutherian mammals. In: Benton MJ, editor. The phylogeny and classification of the tetrapods. Systematics Assoc Spec, vol 35(2). Oxford: Clarendon; 1988. p. 31-73.

Osborn HF. The titanotheres of ancient Wyoming, Dakota, and Nebraska. US Geol Surv Monogr. 1929;55:1-953.

Prothero DR. Ungulate phylogeny: morphological vs. molecular evidence. In: Szalay FS, Novacek MJ, McKenna MC, editors. Mammal phylogeny. Vol. II: placentals. New York: Springer; 1993. p. 173-81.

Prothero DR. Mammalian evolution. In: Prothero DR, Schoch RM, editors. Major features of vertebrate evolution. Short courses in paleontology, vol 7. Knoxville: Paleontological Society; 1994. p. 238-70.

Prothero DR. Camelidae. In: Prothero DR, Emry RJ, editors. The terrestrial Eocene-Oligocene transition in North America. Cambridge, MA: Cambridge University Press; 1996. p. 591-633.
Prothero DR. Rhinocerotidae. In: Janis C, Scott KM, Jacobs LL, editors. Evolution of tertiary mammals of North America. Cambridge, MA: Cambridge University Press; 1998. p. 595-605.

Prothero DR. The evolution of North American Rhinoceroses. Cambridge, UK: Cambridge University Press; 2005.

Prothero DR. Evolution: what the fossils say and why it matters. New York, NY: Columbia University Press; 2007.

Prothero DR, Foss SE, editors. . The evolution of artiodactyls. Baltimore, MD: Johns Hopkins University Press; 2007.

Prothero DR, Schoch RM, editors. . The evolution of perissodactyls. New York, NY: Oxford University Press; 1989.

Prothero DR, Schoch RM. Horns, tusks, and flippers: the evolution of hoofed mammals. Baltimore, MD: Johns Hopkins University Press; 2002.

Prothero DR, Shubin N. The evolution of Oligocene horses. In: Prothero DR, Schoch RM, editors. The evolution of perissodactyls. New York: Oxford University Press; 1989. p. 142-75.

Prothero DR, Manning EM, Hanson CB. The phylogeny of the Rhinocerotoidea (Mammalia, Perissodactyla). Zool J Linn Soc Lond. 1986;87:341-66. doi:10.1111/j.1096-3642.1986.tb01340.x.

Prothero DR, Manning EM, Fischer M. The phylogeny of the ungulates. In: Benton MJ, editor. The phylogeny and classification of the tetrapods. Systematics Assoc Spec, vol 35(2). Oxford: Clarendon; 1988. p. 201-34.

Prothero DR, Guérin C, Manning E. The history of the Rhinocerotoidea. In: Prothero DR, Schoch RM, editors. The evolution of perissodactyls. New York, NY: Oxford University Press; 1989. p. 322-40.

Radinsky LB. The adaptive radiation of the phenacodontid condylarths and the origin of the Perissodactyla. Evolution. 1966;20:408-17. doi:10.2307/2406639.

Radinsky LB. The early evolution of the Perissodactyla. Evolution. 1969;23:308-28. doi:10.2307/2406794.

Rose KD. The beginning of the age of mammals. Baltimore, MD: Johns Hopkins University Press; 2006.

Sarfati J. Refuting evolution 2. Green Forest, AR: Master Books; 2002.

Scheele WE. The first mammals. New York, NY: World; 1955.

Scott WB. A history of land mammals in the western hemisphere. New York, NY: Macmillan; 1913.

Shoshani J, Tassy P. The Proboscidea: evolution and palaeoecology of elephants and their relatives. New York, NY: Oxford University Press; 1996.

Simpson GG. Horses: the story of the horse family in the modern world and through sixty million years of history. Oxford, UK: Oxford University Press; 1951.

Springer MS, Stanhope MJ, Madsen O, de Jong WW. Molecules consolidate the placental mammal tree. Trends Ecol Evol. 2004;19:430-8. doi:10.1016/j.tree.2004.05.006.

Stucky RK. Eocene bunodont and bunoselenodont Artiodactyla ("dichobunids"). In: Janis C, Scott KM, Jacobs LL, editors. Evolution of tertiary mammals of North America. Cambridge, MA: Cambridge University Press; 1998. p. 358-74.

Theodor JM, Rose KM, Erfurt J. Artiodactyla. In: Rose KD, Archibald JD, editors. The rise of placental mammals. Baltimore, MD: Johns Hopkins University Press; 2005. p. 215-33.

Thewissen JBM, Domning DP. The role of phenacodontids in the origin of the modern orders of ungulate mammals. J Vert Paleo. 1992;21:98-106. doi:10.1671/0272-4634(2001)021[0098: SOMEHM]2.0.CO;2.

Wells J. Icons of evolution: science or myth? Why much of what we teach about evolution is wrong. Washington, DC: Regnery; 2000. 